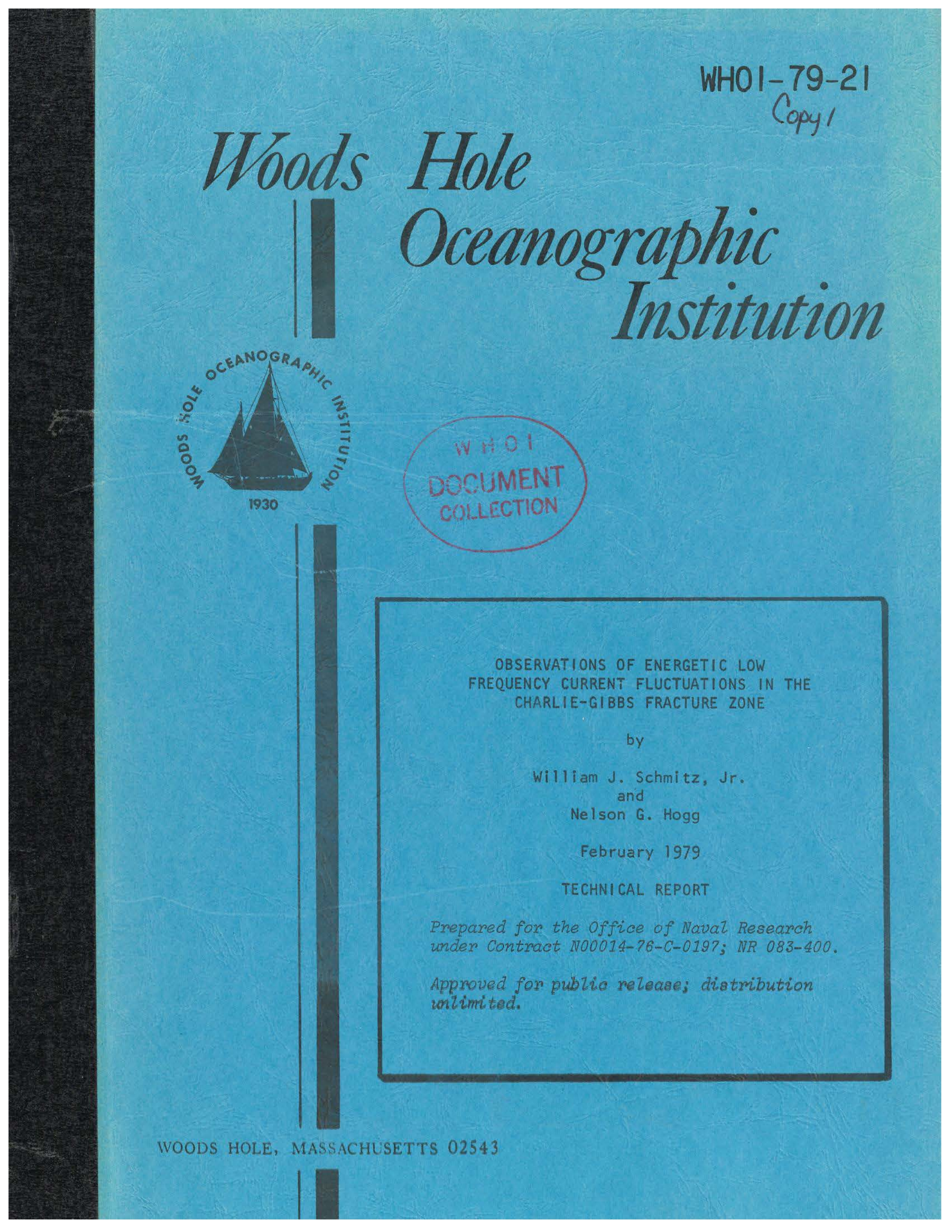


WHOI-79-21

\title{
OBSERVATIONS OF ENERGETIC LOW FREQUENCY CURRENT FLUCTUATIONS IN THE CHARLIE-GIBBS \\ FRACTURE ZONE
}

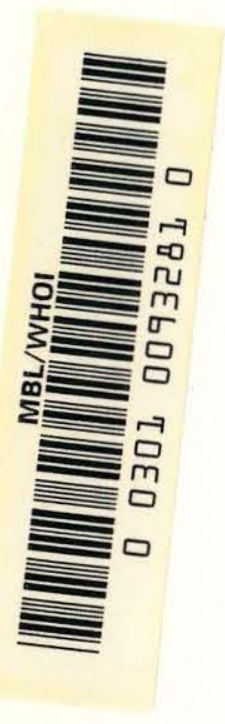

\author{
by \\ William J. Schmitz, Jr. \\ and \\ Nelson G. Hogg \\ WOODS HOLE OCEANOGRAPHIC INSTITUTION \\ Woods Hole, Massachusetts 02543 \\ February 1979
}

TECHNICAL REPORT

Prepared for the Office of Naval Research under Contract N00014-76-C-0197; NR 083-400.

Reproduction in whole or in part is permitted for any purpose of the United States Government. In citing this report in a bibliography, the reference given should be to "Joumal of Marine Research, Volume 36, 4, 1978, pp. 725-734".

Approved for public release; distribution unlimited.

Approved for Distribution: Valentine Worthington, Chairman Department of Physical Oceanography 


\title{
Observations of energetic low frequency current fluctuations in the Charlie-Gibbs Fracture Zone
}

\author{
by William J. Schmitz, Jr. ${ }^{1}$ and Nelson G. Hogg ${ }^{1}$
}

\begin{abstract}
Relatively energetic low frequency fluctuations in horizontal currents are found to exist below the thermocline in the northern trough of the Charlie-Gibbs Fracture Zone. For example, deep eddy kinetic energy levels there are about twice as large as those observed at similar relative depths in the MODE-I region. Eddy kinetic energies are about 2-10 times larger than mean kinetic energies. The vertical distribution of eddy kinetic energy is frequency dependent, increasing toward the thermocline for the longer time scales and intensifying toward the bottom at higher frequencies. In addition to the expected mean westward motion of Norwegian Sea Overflow Water through the northern trough of the fracture, rather consistent mean southward flow is observed at a depth immediately above the overflow.
\end{abstract}

\section{Introduction}

An exploratory array of moored current meters was set below the main thermocline in the northern trough of the Charlie-Gibbs Fracture Zone (hereafter CGFZ) in September, 1975 and recovered in June, 1976. This effort was part of a cooperative investigation involving marine geologists, chemists, and physical oceanographers at the Woods Hole Oceanographic Institution and the Scripps Institution of Oceanography. In addition to the long-term moorings, hydrocasts were made, a deeptowed (sonar, camera, and seismic) profiler survey was carried out (Lonsdale and Shor, 1978), and short-term records were obtained from current meters moored with the acoustic transponder net used to navigate the deep-towed instrument system. We concentrate in the following on the long-term moored instrument observations, with some attention to the hydrocast data. The locations of both are superimposed (Fig. 1) on a chart of the regional topography, adapted from Lonsdale and Shor (1978), and from Shor et al., (1978). In Figure 1, the area to the west of the MidAtlantic Ridge in the northern North Atlantic is indirectly referred to as the Newfoundland Basin, but we adhere otherwise to the nomenclature (Labrador Basin) adopted by Worthington (1976; Fig. 31, p. 79), where likewise the area to the east of the ridge is referred to as the European Basin.

1. Woods Hole Oceanographic Institution, Woods Hole, Massachusetts, 02543, U.S.A. 


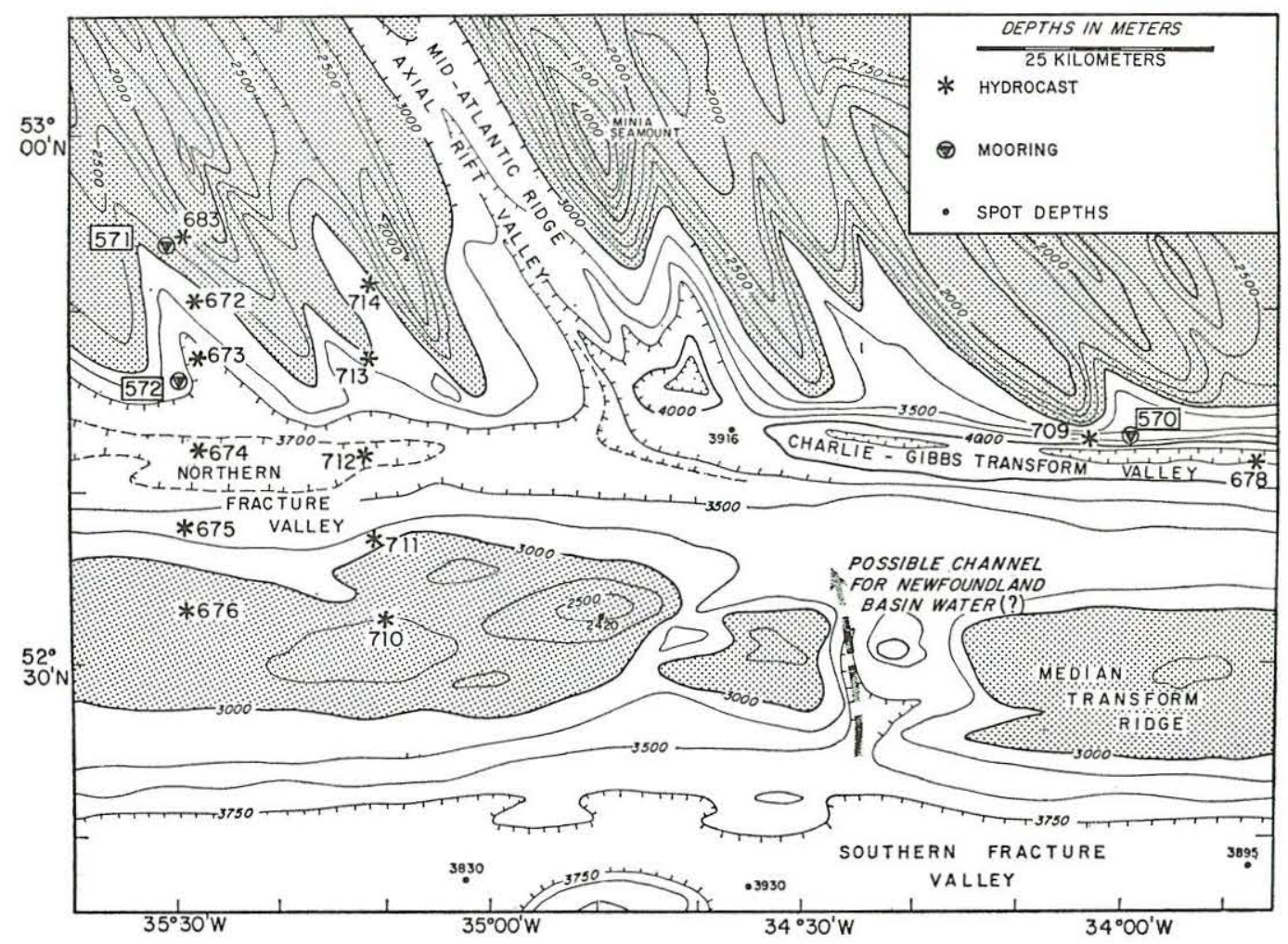

Figure 1. Bathymetry for a portion of CGFZ, with mooring and hydrocast locations superimposed. Adapted from Lonsdale and Shor (1978) and Shor et al., (1978), with a question mark appended to their arrow (near $34^{\circ} 30^{\prime} \mathrm{W}, 52^{\circ} 30^{\prime} \mathrm{N}$ ) indicating a flow from the southern to northern trough of CGFZ (see text). Areas with depths less than $3000 \mathrm{~m}$ are stippled.

The primary objective of the moored instrument and hydrographic observations was to examine the general circulation in CGFZ, with particular emphasis on its geological effects (Shor et al., 1978). Attention was initially focused on the passage of Norwegian Sea Overflow Water from the European Basin through the northern trough of CGFZ into the Labrador Basin, the associated distribution of water properties, suspended particles, and sediments, and a controversial (Worthington and Wright, 1971) hypothesis by Le Pichon, Eittreim and Ewing (1971a, b) of a near bottom flow in the opposite direction.

A secondary objective, preliminary description of the basic properties of the low frequency variability (interchangeably referred to as "eddies," and defined for present purposes to be fluctuations with periods longer than two days and shorter than general circulation time scales), is contained in the following. Previous direct measurements in CGFZ were logistically limited to approximately one day duration 
Table 1. Mooring locations and depths, instrument depths, and data duration.

$\begin{array}{cccccc}\text { Record \# } & \text { Location } & \begin{array}{c}\text { Depth } \\ (\mathrm{m})\end{array} & \begin{array}{c}\text { Bottom } \\ \text { Depth }(\mathrm{m})\end{array} & \begin{array}{c}\text { Date Set } \\ \text { Sept. 26, 1975 }\end{array} & \begin{array}{c}\text { Duration } \\ \text { (days) }\end{array} \\ 5701 & 52^{\circ} 42.7^{\prime} \mathrm{N} . & 4227 & 4311 & & 269 \\ & 33^{\circ} 59.2^{\prime} \mathrm{W} . & & & & \\ 5711 & 52^{\circ} 53.7^{\prime} \mathrm{N} . & 1007 & 2895 & \text { Sept. 27, 1975 } & 270 \\ 5712 & 35^{\circ} 31.0^{\prime} \mathrm{W} . & 2537 & & & 35 \\ 5713 & & 2835 & & & 270 \\ 5721 & & & & & \\ 5722 & 32^{\circ} 46.1^{\prime} \mathrm{N} . & 988 & 3398 & & 270 \\ 5723 & & 2528 & & & 270 \\ 5724 & & 3060 & & & 270\end{array}$

(Worthington and Volkmann, 1965) and about seven days duration (Garner, 1972). The principal qualitative result, discussed below, is the discovery of a comparatively energetic deep eddy field, with a frequency dependent vertical structure. We also discuss briefly some characteristics of the time-averaged flow.

\section{Method}

All moorings set were retrieved without difficulty. Seven of the eight current meters deployed yielded good quality data for the duration of the experiment; one record is short. Locations, current meter depths and data duration are noted in Table 1. In Table 1 and the following, the first three digits of the record number identify the mooring number (assigned sequentially as deployed), and the fourth digit is the number of the instrument on the mooring (assigned sequentially from top to bottom).

Basic time averages for the eddy field are listed in Table 2. These averages were obtained with the low-pass filter described by Schmitz (1974), and have been re-

Table 2. Basic time averages for the low frequency variability. Symbols are defined in the text. $\left(\bar{u}, \bar{v}, K_{M}\right)$ were calculated over the data durations listed in Table $1 .\left(\overline{u^{\prime 2}}, \overline{v^{\prime 2}}, K_{E}(T)\right)$ were calculated over a uniform 260 day duration.

$\begin{array}{cccccrrr}\text { Record \# } & \begin{array}{c}\text { Depth } \\ (\mathrm{m})\end{array} & \begin{array}{c}\bar{u} \\ \left(\mathrm{~cm} \mathrm{~s}^{-1}\right)\end{array} & \begin{array}{c}\bar{v} \\ \left(\mathrm{~cm} \mathrm{~s}^{-1}\right)\end{array} & \begin{array}{c}K_{M} \\ \left(\mathrm{~cm}^{2} \mathrm{~s}^{-2}\right)\end{array} & \begin{array}{c}\overline{u^{\prime 2}} \\ \left(\mathrm{~cm}^{2} \mathrm{~s}^{-2}\right)\end{array} & \begin{array}{c}\overline{v^{2}} \\ \left(\mathrm{~cm}^{2} \mathrm{~s}^{-2}\right)\end{array} & \begin{array}{c}K_{E}(T) \\ \left(\mathrm{cm}^{2} \mathrm{~s}^{-2}\right)\end{array} \\ 5701 & 4277 & -4.1 & -.6 & 8.6 & 40.5 & 2.2 & 21.4 \\ 5711 & 1007 & -1.6 & -3.8 & 8.5 & 12.3 & 17.0 & 14.6 \\ 5713 & 2835 & -.4 & .7 & .3 & 4.4 & 5.8 & 5.1 \\ 5721 & 988 & 1.4 & -3.3 & 6.4 & 37.6 & 40.6 & 39.1 \\ 5722 & 2528 & -4.4 & -1.6 & 11.0 & 34.2 & 9.0 & 21.6 \\ 5723 & 3060 & -3.8 & -1.0 & 7.7 & 42.3 & 6.1 & 24.2 \\ 5724 & 3360 & -3.2 & -2.1 & 7.3 & 34.4 & 11.1 & 22.8\end{array}$


Table 3. Eddy kinetic energies $\left(\mathrm{cm}^{2} \mathrm{~s}^{-2}\right)$ for indicated records and ranges of periods ( $\tau$, days).

$\begin{array}{cccc} & \text { Band 1 } & \text { Band } 2 & \text { Band 3 } \\ \text { Record \# } & (48 \leqslant \tau \leqslant 520) & (17 \leqslant \tau \leqslant 48) & (8.5 \leqslant \tau \leqslant 17) \\ 5721 & 24.3 & 10.1 & 2.9 \\ 5722 & 8.6 & 7.0 & 3.1 \\ 5723 & 8.9 & 7.3 & 4.2 \\ 5724 & 4.8 & 7.8 & 5.0 \\ & \text { Band 4 } & \text { Bands } 2+3+4 & \\ & (2 \leqslant \tau \leqslant 8.5) & (2 \leqslant \tau \leqslant 48) & \\ & 1.8 & 14.8 & \\ & 3.0 & 13.1 & \\ & 3.7 & 15.2 & \\ & 5.2 & 18.0 & \end{array}$

normalized to remove the effects of the filter on fluctuations with periods longer than two days. The symbols used in Table 2 and throughout this investigation $\left(\bar{u}, \bar{v}, K_{M}\right.$, $\overline{u^{\prime 2}}, \overline{v^{\prime 2}}, K_{E}$ ) are defined to be (time-mean east velocity component, time-mean north velocity component, kinetic energy per unit mass for the time-averaged flow, variance of east-west low frequency motions, variance of north-south low frequency motions, eddy kinetic energy per unit mass). The per unit mass is hereafter understood.

For the purpose of examining spectral properties of the low frequency segment of the data, each record (subsampled once per day) was truncated to arrive at a uniform 260 day duration. The highest "eddy" frequency band is $(1 / 2$ to $1 / 2-1 / 520)$ cycles per day (c.p.d.) and the lowest is $(1 / 260 \pm 1 / 520)$ c.p.d. Temporal means $\left(\bar{u}, \bar{v}, K_{M}\right)$ contain contributions from frequencies between 0 and 1/520 c.p.d. The symbol $K_{E}(T)$ will be used to denote the kinetic energy associated with the entire range ( $T$ denotes total) of "eddy" frequencies accessible, 1/520 to 1/2 c.p.d. Four adjacent frequency $(\nu)$ bands in this range have been selected for more detailed examination (Table 3). $D\left(K_{E}\right)$ will denote $d K_{E} / d\left(\log _{10} \nu\right)$, to be plotted against $\log _{10} \nu$ in the following for spectral plots that are energy preserving by area. These plots are presented in the form of bar graphs in order to call attention to the bandwidth of the estimates.

\section{Energy levels and time scales}

$K_{E}(T)$ values in Table 2 vary by approximately an order of magnitude, and are a factor of 2 to over an order of magnitude larger than $K_{M I} . K_{E}(T)$ for the mooring (571) on an indentation in the slope associated with the Reykjanes Ridge is significantly lower than for the mooring (572) to the south in the northern trough of CGFZ, by a factor of about 3 near $1000 \mathrm{~m}$ depth, and about 5 near $3000 \mathrm{~m}$ depth. 


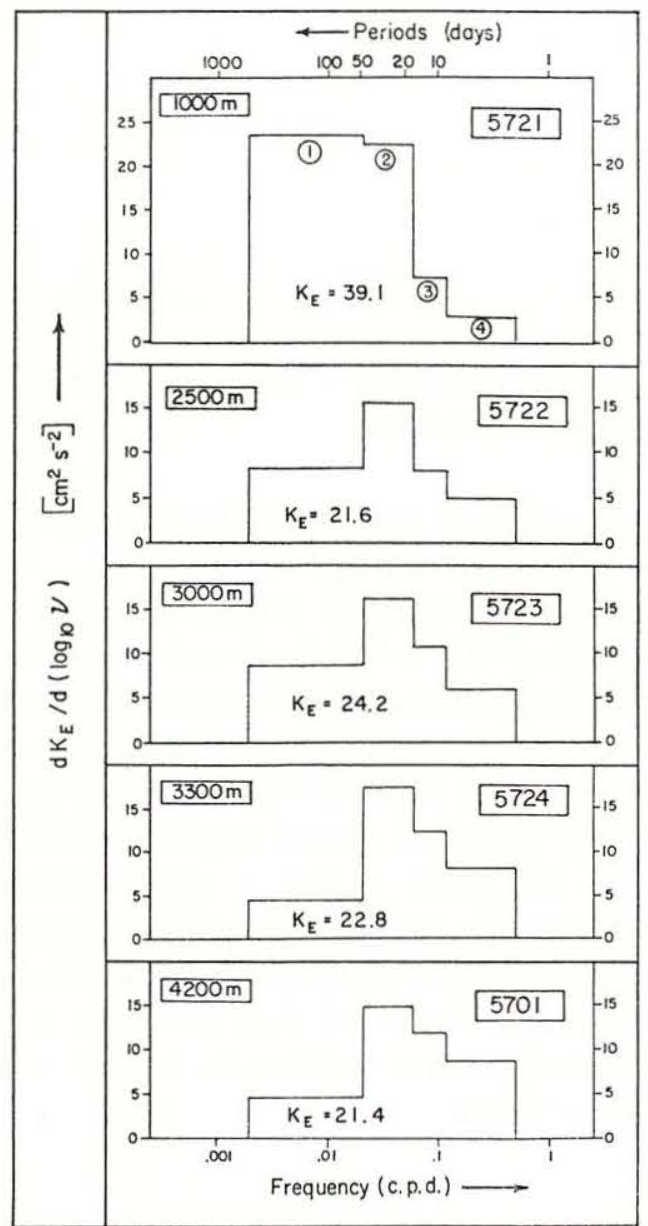

Figure 2. Decadal spectral estimates for indicated records and depths (nominal). The circled numbers in the top frame of the figure refer to the frequency bands described in the text and listed in Table 3. The values of $K_{E}$ inside the bar graphs denote the area under the curve (or total eddy kinetic energy) in $\mathrm{cm}^{2} \mathrm{~s}^{-2}$.

Energy levels at depths of $2500 \mathrm{~m}$ and below for the moorings $(570,572)$ in the trough are roughly twice those found at comparable relative depths in, for example, the MODE-I area (Richman, Wunsch and Hogg, 1977; Schmitz, 1976, 1977, 1978).

Estimates of the decadal or logarithmic (energy preserving by area) kinetic energy frequency spectra from 572 and 5701 contain relatively more energy at shorter time scales with increasing depth (Fig. 2). $D\left(K_{E}\right)$ at $1000 \mathrm{~m}$ in Figure 2 is essentially red, but at depths of $2500 \mathrm{~m}$ and below, reaches a maximum at periods of 17-48 days. $K_{E}$ summed over periods less than 48 days (Table 3, column labeled Bands 


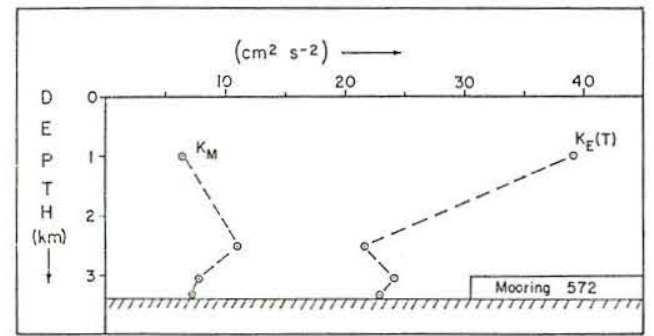

Figure 3. Vertical distributions of total eddy kinetic energy $\left[K_{E}(T)\right]$ and the kinetic energy of the time-mean flow $\left(K_{M}\right)$ for mooring 572.

$2+3+4$ ) is larger than $K_{E}$ summed over periods longer than 48 days (Table 3, Band 1) at all depths below $1000 \mathrm{~m}$ on mooring 572.

Any seasonal variability that might be present would be contained in Band 1 (contributions from periods of 48 to 520 days), and cannot be identified inside this band with any real confidence. Shor et al. (1978) note that monthly averages of the zonal current component from records $5722 \rightarrow 5724$ are a minimum in December $\rightarrow$ February and suggest seasonal bottom water formation, phase lagged by about 6 months in CGFZ from the Iceland-Faroe Ridge. But 5701, presumably as much in the overflow as 572 , does not show a similar behavior in monthly zonal means. We do not wish to rule out seasonal and/or generally intermittent water mass formation, but rather to point to the difficulty of drawing conclusions based on the data in question. Aagaard and Malmberg (1978) have pointed out the probable dominance of two day (nominal) fluctuations, relative to seasonal, in the overflow through the Denmark Straits.

\section{Vertical structure}

$K_{E}(T)$ for mooring 572 (Table 2, Fig. 3) is roughly twice as large at $1000 \mathrm{~m}$ depth (nominal) as in the $2500-3400 \mathrm{~m}$ depth range (nominal), over which the variation in $K_{E}(T)$ is quite small $(\sim 15 \%)$. The total zonal component (roughly along depth contours) of the low frequency variance for mooring 572 (Table 2 ) is not very depth dependent, so that vertical variations in $K_{E}(T)$ are primarily determined by the cross-isobath (roughly meridional) flow, which is substantially less $(\sim$ a factor of 4-7) energetic at depths within the confines of the trough than at $1000 \mathrm{~m}$ depth.

The vertical distribution of $K_{E}$ for each of the 4 frequency bands in Figure 2 is contained in Figure 4. $K_{E}$ for the lowest frequency band increases sharply upward. The highest frequencies (Bands 3 and 4) are bottom intensified. Band 2 is an intermediate case.

\section{Mean flow}

Eddy kinetic energies were found to be 2-10 times larger than mean kinetic ener- 


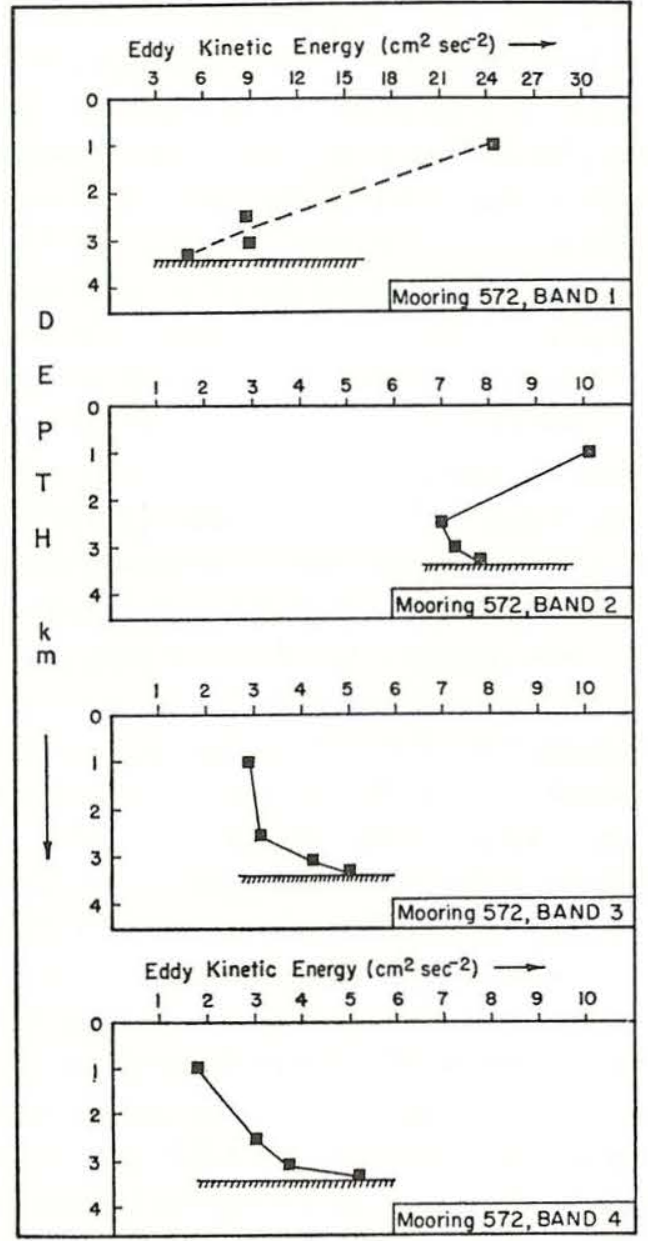

Figure 4. Vertical distributions of eddy kinetic energy at mooring 572 for the frequency bands listed in Table 3 and circled in Figure 2.

gies, thereby precluding short term measurements as a basis for accurate estimates of the intensity of the mean flow (general circulation). Nevertheless, the mean zonal flows (3-4 $\mathrm{cm} \mathrm{s}^{-1}$ to the west) for the deep instruments on mooring 572 and at 5701 are very close to those found by Garner (1972) during a 7 day moored instrument deployment. Worthington and Volkmann (1965) obtained two roughly 30 hour duration moored instrument records with westward means of about 4 and $8 \mathrm{~cm} \mathrm{~s}^{-1}$ at 2500-2800 depths, and also roughly 3 and $12 \mathrm{~cm} \mathrm{~s}^{-1}$ from neutrally buoyant floats in the same depth range, of approximate duration 30 and 15 hours respectively.

Shor et al., (1978) discuss the deep mean flow in CGFZ in some detail. We would 
in addition like to call attention to the pronounced southward component of the mean flow at $1000 \mathrm{~m}$ depth (nominal) at both moorings 572 and 571 (Table 2). Current meters were deployed near $1000 \mathrm{~m}$ depth because Worthington and Volkmann (1965) suggested a level of no motion there, due to location at a break in the $\theta / S$ curve, identified with a transition from the more saline overflow water to "resident" North Atlantic Deep Water. The zonal mean flows at 5711 and 5721 are not large, and differ in sign, but the meridional means are consistent in both magnitude and sign and roughly the same size as the zonal means found in the overflow depth range. These southerly means could be associated with a branch of the "Atlantic Current" described by Ivers (1975), or possibly (a definite speculation) part of an enlarged and/or modified version of the flow patterns described by either Mann (1967) and Reiniger and Clarke (1975), or by Worthington (1976).

Although Shor et al., (1978) note the expected westward mean flow of Norwegian Sea Overflow Water, they also found water of western origin (their Fig. 5) in the western part of CGFZ. They suggest a complex flow pattern in order to rationalize this observation, involving eastward mean flow in the southern trough, entry into the northern trough through a break in the median ridge, and then westward mean flow in the northern trough (Fig. 1). But the penetration scale of water of western basin characteristics into CGFZ, about $200 \mathrm{~km}$, is roughly the advective length scale ( $4 \mathrm{~cm} \mathrm{~s}^{-1} \times 50$ days) of the deep eddies, raising the possibility that the existence of such water at depth in CGFZ might be due to either time-dependent or diffusive effects, rather than advection by a mean flow. In addition, the pattern suggested by Shor et al., (1978) at least partially conflicts with the observations by Garner (1972), who found a westward mean in the southern as well as the northern trough of CGFZ. Therefore, we suggest that it may not be necessary to invoke an involved pattern for the general circulation in CGFZ, and we have accordingly appended a question mark to this suggestion on Figure 1. John G. Harvey (personal communication) has suggested that the totality of hydrographic data available from CGFZ does demonstrate the existence of western basin water as far east as roughly $35^{\circ} 30^{\prime} \mathrm{W}$, but not as far east as the break in the median ridge indicated on Figure 1. $\mathrm{He}$ also questions an interpretation of topographic data that yields the existence of the break.

\section{Summary and conclusions}

Exploratory long-term $(\sim$ nine month duration) moored instrument data were obtained from depths below the thermocline in the northern trough of CGFZ. These new long-term data are the first permitting examination of the basic properties of the eddy field in this area.

Energetic eddies were found, horizontally inhomogeneous across depth contours. The overall eddy field at the main mooring was relatively depth independent in its component along depth contours, with the cross isobath component decreasing 
moving from the bottom of the thermocline toward the sea floor. The vertical distribution of $K_{E}$ is frequency dependent, increasing toward the thermocline for the longer time scales and toward the bottom at shorter time scales. The relative amplitudes are such that $K_{E}$ at $1000 \mathrm{~m}$ is more weighted toward longer time scales, and is larger than $K_{E}$ in the $2500 \mathrm{~m}$ to sea floor depth range where $K_{E}$ associated with 50 day (nominal) periods and less exceeds $K_{E}$ associated with the longer time scale variability. This type of vertical variation of $K_{E}$ and of spectral shape is similar to the general character of what is known about low frequency fluctuations in much of the western North Atlantic (Schmitz, 1978).

The time-averaged zonal flows at depths of $2500 \mathrm{~m}$ and larger were: (a) somewhat surprisingly close to those found by Garner (1972) on the basis of weekly averages, and (b) on the low side of those reported by Worthington and Volkmann (1965) on the basis of 15 to 30 hour averages. A mean meridional flow component was observed at $1000 \mathrm{~m}$ depth, immediately above the Norwegian Sea Overflow Water, with amplitude essentially the same as for the zonal overflow.

The data discussed above were collected in the northern portion of the northern trough in CGFZ only, and all conclusions should be restricted accordingly, with particular attention to those bearing on temporal means and/or the general circulation. Answers to many of the questions that have been raised concerning the pattern of the mean flow and the properties of the eddy field in CGFZ will require additional measurements in other areas such as the southern region of the northern trough, the southern trough, and also along the median ridge. The resolution of seasonal and longer time scales and the general problem of intermittent water mass formation and transport will necessitate much longer data series.

Acknowledgments. This is contribution number 4141 from the Woods Hole Oceanographic Institution, an investigation supported by the Office of Naval Research under Contract N0001476-C-0197, NR 083-400. The moored instrument data presented were collected and processed by the Buoy Group at the Woods Hole Oceanographic Institution, and their support is gratefully acknowledged. John G. Harvey made some particularly constructive suggestions during manuscript review and revision. We are grateful to Sandy Shor for providing the basis of Figure 1 and in general for a very open exchange of data and ideas throughout our collaboration.

\section{REFERENCES}

Aagaard, K., and S.-A. Malmberg. 1978. Observational Summary, MONA-5, MONA-6. Informal report of the Overflow Working Group, I.C.E.S., 17 May 1978.

Garner, D. M. 1972. Flow through the Charlie-Gibbs Fracture Zone, Mid-Atlantic Ridge, Canadian Jour. of Earth Sci., 9, 116-121.

Ivers, W. D. 1975. The deep circulation in the northern North Atlantic, with especial reference to the Labrador Sea, Ph.D. Dissertation, University of California, San Diego.

LePichon, X., S. Eittreim, and J. Ewing. 1971a. A sedimentary channel along Gibbs Fracture Zone, J. Geophys. Res., 76, 2891-2896.

1971b. Reply to discussion by L. V. Worthington and W. R. Wright, J. Geophys. Res., 76, 6609-6612. 
Lonsdale, P., and A. Shor. 1978. The oblique intersection of the Mid-Atlantic Ridge with Charlie-Gibbs transform fault. Tectonophysics, in press.

Mann, C. R. 1967. The termination of the Gulf Stream and the beginning of the North Atlantic Current, Deep-Sea Res., 9, 51-67.

Reiniger, R. F., and R. A. Clarke. 1975. Circulation pattern in the Newfoundland Ridge area, 1972, International Commission for the Northwest Atlantic Fisheries, Special Publication No. $10,57-67$.

Richman, J. R., C. Wunsch, and N. Hogg. 1977. Space and time scales of mesoscale motion in the western North Atlantic. Rev. Geophys. and Space Phys., 15, 385-420.

Schmitz, W. J., Jr. 1974. Observations of low frequency current fluctuations on the Continental Slope and Rise near Site D. J. Mar. Res., 32, 233-251.

1976. Eddy-kinetic energy in the deep western North Atlantic. J. Geophys. Res., 81, 49814982.

1977. On the deep general circulation in the western North Atlantic. J. Mar. Res., 35, 21-28.

- 1978. Observations of the vertical structure of low frequency fluctuations in the western North Atlantic. J. Mar. Res., 36, 295-310.

Shor, A., P. Lonsdale, C. Hollister, and D. Spencer. 1978. Charlie-Gibbs Fracture Zone: Deep and bottom water transport. Manuscript, personal communication.

Worthington, L. V. 1976. On the North Atlantic Circulation. Johns Hopkins Oceanographic Studies, Vol. VI. The Johns Hopkins University Press, Baltimore and London, $110 \mathrm{pp}$.

Worthington, L. V., and G. H. Volkmann. 1965. The volume transport of the Norwegian Sea outflow in the North Atlantic, Deep-Sea Res., 12, 667-676.

Worthington, L. V., and W. R. Wright. 1971. Discussion of a paper by X. LePichon, S. Eittreim, and J. Ewing: "A sedimentary channel along Gibbs Fracture Zone," J. Geophys. Res., 76, 6606-6608.

Received: 16 May, 1978; revised: 5 September, 1978.

Printed in U.S.A. for the Sears Foundation for Marine Research, Yale University, New Haven, Connecticut, 06520, U.S.A.

Van Dyck Printing Company, North Haven, Connecticut, 06473, U.S.A. 


\section{MANDATORY DISTRIBUTION LIST}

FOR UNCLASSIFIED TECHNICAL REPORTS, REPRINTS, AND FINAL REPORTS

PUBLISHED BY OCEANOGRAPHIC CONTRACTORS

OF THE OCEAN SCIENCE AND TECHNOLOGY DIVISION

OF THE OFFICE OF NAVAL RESEARCH

(REVISED NOVEMBER 1978)

1 Deputy Under Secretary of Defense (Research and Advanced Technology) Military Assistant for Environmental Science Room 3D129

Washington, D.C. 20301

Office of Naval Research

800 North Quincy Street

Arlington, VA 22217

ATTN: Code 483

ATTN: Code 460

ATTN: 102B

1 CDR J. C. Harlett, (USN) ONR Representative Woods Hole Oceanographic Inst.

Woods Hole, MA 02543

Commanding Officer

Naval Research Laboratory Washington, D.C. 20375

6 ATTN: Library, Code 2627
12 Defense Documentation Center Cameron Station

Alexandria, VA 22314

ATTN: DCA

Commander

Naval Oceanographic Office NSTL Station

Bay St. Louis, MS 39522

ATTN: Code 8100

ATTN: Code 6000

ATTN: Code 3300

$1 \quad$ NODC/NOAA

Code D781

Wiscons in Avenue, N.W. Washington, D.C. 20235 



\begin{tabular}{|c|c|}
\hline REPORT DOCUMENTATION PAGE & $\begin{array}{l}\text { READ INSTRUCTIONS } \\
\text { BEFORE COMPLETING FORM }\end{array}$ \\
\hline $\begin{array}{l}\text { 1. REPORT NUMBER } \\
\qquad \text { WHOI-79-21 }\end{array}$ & 3. RECIPIENT'S CATALOG NUMBER \\
\hline $\begin{array}{l}\text { 4. TITLE (and Subitle) } \\
\text { OBSERVATIONS OF ENERGETIC LOW FREOUENCY CURRENT }\end{array}$ & $\begin{array}{l}\text { 5. TYPE OF REPORT \& PERIOD COVERED } \\
\text { Technical }\end{array}$ \\
\hline FLUCTUATIONS IN THE CHARLIE-GIBBS FRACTURE ZONE & $\begin{array}{l}\text { 6. PERFORMING ORG REPORT NUMBER } \\
\text { WHOI CON. NO. } 4141^{\text {N }}\end{array}$ \\
\hline $\begin{array}{l}\text { 7. AUTHOR(a) } \\
\text { William J. Schmitz, Jr. and Nelson G. Hogg }\end{array}$ & $\begin{array}{l}\text { 8. CONTRACT OR GRANT NUMBER(O) } \\
\text { N00014-76-C-0197; }\end{array}$ \\
\hline $\begin{array}{l}\text { 9. PERFORMING ORGANIZATION NAME AND ADDRESS } \\
\text { Woods Hole Oceanographic Institution } \\
\text { Woods Hole, MA } 02543\end{array}$ & $\begin{array}{l}\text { 10. PROGRAM ELEMENT, PROJECT, TASK } \\
\text { AREA \& WORK UNIT NUMBERS } \\
\text { NR } 083-400\end{array}$ \\
\hline $\begin{array}{l}\text { 11. CONTROLLING OFFICE NAME AND ADDRESS } \\
\text { NORDA }\end{array}$ & $\begin{array}{l}\text { 12. REPORT DATE } \\
\text { FEbruarY } 1979\end{array}$ \\
\hline $\begin{array}{l}\text { National Space Technology Laboratory } \\
\text { Bay St. Louis, MS } 39529\end{array}$ & 13. NUMBER OF PAGES \\
\hline 14. MONITORING AGENCY NAME \& ADDRESS(If dilforent from Controlline Oflico) & $\begin{array}{l}\text { 15. SECURITY CLASS. (of thto roport) } \\
\text { Unclassified }\end{array}$ \\
\hline & $\begin{array}{l}\text { 15a. DECLASSIFICATION/DOWNGRADING } \\
\text { SCHEDULE }\end{array}$ \\
\hline
\end{tabular}

16. DISTRIBUTION STATEMENT (of thls Roport)

Approved for public release; distribution unlimited.

17. DISTRIBUTION STATEMENT (of the abatract ontered in Block 20, if difforent from Roport)

18. SUPPLEMENTARY NOTES

Reprinted from "Journal of Marine Research, Volume 36, 4, 1978, pp. 725-734".

19. KEY WORDS (Continue on reverse side if necessary and identify by block number)

1. Charlie-Gibbs Fracture Zone

2. Low-frequency fluctuations

3. General circulation

20. ABSTRACT (Continue on poverao side if neceesary and identify by block number)

Relatively energetic low frequency fluctuations in horizontal currents are found to exist below the thermocline in the northern trough of the CharlieGibbs Fracture Zone. For example, deep eddy kinetic energy levels there are about twice as large as those observed at similar relative depths in the MODE-1 region. Eddy kinetic energies are about 2-10 times larger than mean kinetic energies. The vertical distribution of eddy kinetic energy is frequently dependent, increasing toward the thermocline for the longer (Cont. on

DD, FORM 1473 EDITION OF I NOV 65 IS OBSOLETE S/N $0102-014-6601$ |
UNCLASSIFIED $2 / 79$

SECURITY CLASSIFICATION OF THIS PAGE (When Dala Entered) 
time scales and intensifying toward the bottom at higher frequencies. In addition to the expected mean westward motion of Norwegian Sea Overflow Water through the northern trough of the fracture, rather consistent mean southward flow is observed at a depth immediately above the overflow. 


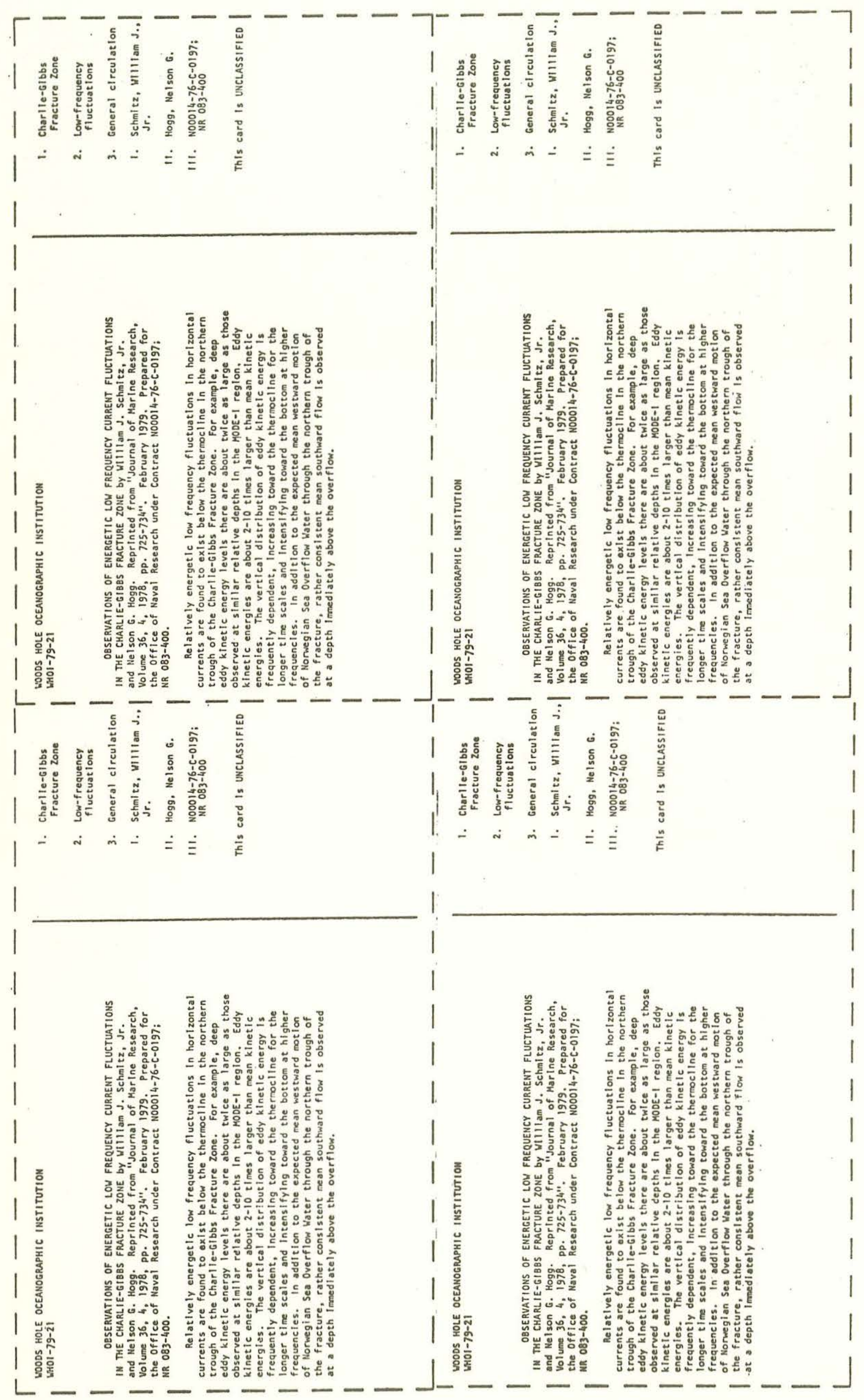

